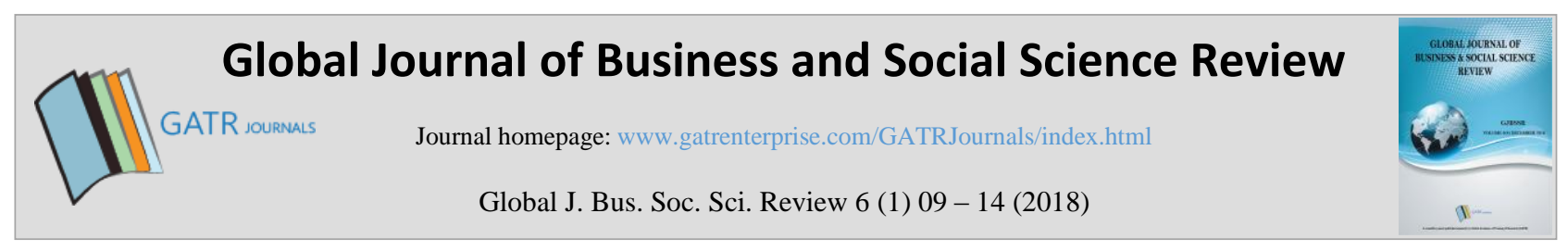

\title{
The Impact of Psychological Capital and Psychological Empowerment on Employee's Affective Commitment to Change
}

\author{
Muthmainah Mufidah ${ }^{1}$, Wustari L. Mangundjaya ${ }^{2} *$ \\ ${ }^{12}$ Faculty of Psychology, Universitas Indonesia, Kampus Baru UI, 1624, Depok, Indonesia
}

\begin{abstract}
Objective - Organizations nowadays have to change and adjust themselves with the changing external environment in order to survive in the globalization era. This change requires a high affective commitment to change from its employees. The purpose of this study is to examine the impact of psychological capital and psychological empowerment on employee's affective commitment to change.

Methodology/Technique - Respondents were 242 employees of Indonesian financial institutions which have undergone organizational changes. Data collection tools were Commitment to Change Inventory, Psychological Empowerment, and Psychological Capital, and was analysed using regression analysis.

Findings - Findings indicated that a positive and significant impact of psychological capital and psychological empowerment on affective commitment to change. This study also found that psychological capital has a more significant influence on affective commitment to change than psychological empowerment.

Research limitations/implications - The implications of the study can be used for managing change better, such as developing confidence in people by developing both psychological empowerment and psychological capital.

Originality/value - Results are essential for managing change better, such as developing confidence in people by promoting both psychological empowerment and psychological capital.
\end{abstract}

Type of Paper: Empirical

Keywords: Affective Commitment to Change; Psychological Capital; Psychological Empowerment; Organizational Change; Financial Institutions.

JEL Classification: J50, J59.

\section{Introduction}

Globalization today is inevitable, the implementation of the ASEAN Economic Community or familiarly called MEA had also affected the financial sector in Indonesia (Prasetyo, 2014).

\footnotetext{
* Paper Info: Revised: December, 19, 2017

Accepted: February, 11, 2018

* Corresponding author:

E-mail:wustari@ui.ac.id; wustari@gmail.com

Affiliation: Faculty of Psychology, Universitas Indonesia
} 
Pressures from the external environment described above made the organization needed to do some changes in order to survive and developed better in the globalization (Palmer, Dunford, and Akin, 2009). However, previous studies showed that 70-90\% of the change programs were not successful (Fulcher, 2013), and people were said as one of the most important factors (Robbins, 2013). In this regard, people should have the commitment to change (Mangundjaya, 2016). Herscovitch and Meyer (2002) describe affective commitment to change in the organization as a desire within the individual to provide support for change on the basis of a belief that change can be good for the organization. From the three dimensions of commitment to change, affective commitment to change is considered to be the most important among the others (Herscovith \& Meyer, 2002; Parish et al., 2008). According to Herscovitch and Meyer (2002), affective commitment to change can become the representative of the commitment to change.

Individual's commitment to change is inseparable from their characteristics (Mangundjaya, 2014). Luthans, Youssef, and Avolio (2007) described a concept of the positive characteristics that individuals have in achieving target and facing the changing situation, as psychological capital. Luthans, Youssef, and Avolio (2007) define psychological capital as an individual's positive psychological state of development and characterized by people having confidence to take necessary effort to succeed in performing tasks, to make a definite attribution about succeeding now and in the future, and has adversity attitude to bounce back to attain success. There are four dimensions of psychological capital, namely a) self-efficacy, self-confidence in individual's ability to drive motivations, cognitive sources, and actions to successfully perform a task in a particular context (Stajkovic and Luthans, 1998), b) optimism, a condition in which individuals attribute events positively (Seligman, 2011) c) hope, individuals favourable motivational condition and determination to start and keep effort in reaching a goal (Snyder, 2000), and d) resilience, a capability to recover from misery, conflict, failure, that a person experiences (Luthans, 2002).

The similar characteristics of psychological capital have developed by Spreitzer (2007) which was called psychological empowerment. Both are the positive characteristics of the individual and considered mutually supportive of each other as to their influence on organizational change. Psychological empowerment emphasizes on controling the environment and competence (Spreitzer, 2007). Spreitzer (2007) defines psychological empowerment as a set of psychological states which are necessary for people to feel a sense of control of their work. Psychological empowerment is explained Spreitzer (2007) as a motivational construct manifested from four dimensions, namely a) meaning, as the value owned by employees in the goals or targets to be achieved, b) competence, as a trust owned by the individuals about their ability to perform correctly and competently, c) self-determination, is an individual's view of themselves about the choice to initiate, and d) impact as the degree to which the individual feels that one is capable of influencing the work.

Meanwhile, psychological capital is not about control, but about the four characteristics (self-efficacy, optimism, hope, and resilience) that can be used in managing change. The objective of this study was to test the impact of psychological capital and psychological empowerment on affective commitment to change and to identify which one of the two had a stronger impact on affective commitment to change.

People who have high psychological capital which consisted of hope, self-efficacy, resilience, and optimism, are assumed to be having more positive attitude and behavior toward organizational change (Luthans, 2002) as they are confident in facing the organizational change. Meanwhile, people who have high psychological empowerment, which have a high feeling of competence, meaning, determination and impact will also be ready to face the changes (Spreitzer, 2007). Based on these, the following hypotheses were developed:

Hypothesis 1: Psychological capital had a positive impact on affective commitment to change.

Hypothesis 2: Psychological empowerment had a positive impact on affective commitment to change.

Individual readiness for change is related with the commitment to change (Mangundjaya, 2013) and based on Lizar, Mangundjaya, and Rachmawan (2014) findings, showed that psychological empowerment had a more significant impact on individual readiness for a change compared with psychological capital. Based on these, the following hypothesis as follows: 
Hypothesis 3: Psychological empowerment had greater positive impact on affective commitment to change compared with psychological capital.

\section{Methods}

\section{Participants}

The respondents of the study were employees who worked at banking and non-banking financial institutions in Jakarta and surrounding areas, which have been conducted organizational changes. Respondents consisted of 242 permanent employees who have worked for at least two years and had the educational background at least graduated from Senior high school. The profiles of the participants are as

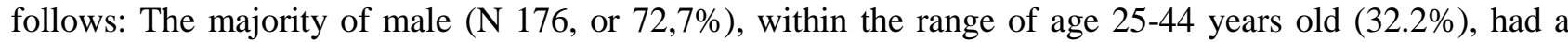
bachelor degree $(68.6 \%)$ and had been working in the company between $2-10$ years $(86.7 \%)$. The complete profile of the respondents can be seen in Table 1.

Table 1. Demographic of Respondents

\begin{tabular}{llll}
\hline \multirow{2}{*}{ Respondent Characteristic } & $\begin{array}{l}\text { Frequency } \\
(\mathrm{N}=242)\end{array}$ & Percentage (\%) \\
\hline \multirow{2}{*}{ Gender } & Women & 66 & $27.3 \%$ \\
& Men & 176 & $72.7 \%$ \\
Age & <25 years old & 78 & $32.2 \%$ \\
& 25-44 years old & 150 & $62 \%$ \\
& $>44$ years old & 14 & $5.8 \%$ \\
\multirow{3}{*}{ Education } & High School & 30 & $12.4 \%$ \\
& D3/D4 (Diploma) & 31 & $12.8 \%$ \\
& S1 (Bachelor) & 166 & $68.6 \%$ \\
\multirow{2}{*}{ Lengths of Work } & S2 and S3 (Master \& PhD) & 15 & $6.1 \%$ \\
& Years & 210 & $86.7 \%$ \\
& $>10$ years & 32 & $13.3 \%$ \\
\hline
\end{tabular}

\section{Data Collection}

Data was collected using three instruments as follows: a) Affective Commitment to Change adopted from Herscovith and Meyer (2002) which had been translated into Bahasa Indonesia by Mangundjaya (2013), b) Psychological Empowerment adopted from Spreitzer (1995) which had been translated into Bahasa Indonesia by Mangundjaya (2014), and c) Psychological Capital from Luthans, Youssef, and Avolio (2007) which translated by Mangundjaya (Lizar, Mangundjaya, \& Rachmawan, 2015).

\section{Data Analysis}

The data were analyzed using SPSS (Statistical Package for the Social Science) software and analyzed using regression analysis. 


\section{Results}

\section{Regression Analysis}

The following table 1 showed the Results of Regression Analysis (Psychological Capital and Psychological Empowerment on Affective Commitment to Change).

Table 1: The results of regression analysis

\begin{tabular}{|c|c|c|c|c|}
\hline & $\begin{array}{l}\text { Standardized } \\
\text { Coefficient } \beta\end{array}$ & $\mathrm{r}$ & $\mathrm{R} 2$ & Sig (p) \\
\hline Psychological Capital & .360 & $.360 * *$ & .130 & $.000 * *$ \\
\hline Self-efficacy & .305 & $.305 * *$ & .09 & $.000^{* *}$ \\
\hline Optimism & .330 & $.330 * *$ & .10 & $.000 * *$ \\
\hline Hope & .345 & $.345^{* *}$ & .11 & $.000 * *$ \\
\hline Resilience & .368 & $.368 * *$ & .13 & $.000 * *$ \\
\hline Psychological Empowerment & .332 & $.332 * *$ & .11 & $.000 * *$ \\
\hline Meaning & .348 & $.348 * *$ & .12 & $.000 * *$ \\
\hline Competence & .332 & $.332 * *$ & .11 & $.000 * *$ \\
\hline Self-determination & .220 & $.220 * *$ & .04 & $.000 * *$ \\
\hline Impact & .242 & $.242 * *$ & .05 & $.000 * *$ \\
\hline \multicolumn{5}{|l|}{ Psychological Empowerment } \\
\hline + Psychological Capital & & $.376^{* *}$ & .141 & $.000 * *$ \\
\hline Psychological Empowerment & .152 & & $\Delta \mathrm{R} 2=.011$ & .079 \\
\hline Psychological Capital & .252 & & $\Delta \mathrm{R} 2=.031$ & $.004 *$ \\
\hline $\mathrm{F}=19.631$ & & & & \\
\hline
\end{tabular}

Findings showed that there was a positive and significant correlation between psychological capital and affective commitment to change, $\mathrm{r}=0.36, \mathrm{p}<0.01$ (one-tailed). Psychological capital had a significant impact on the affective commitment to change $(\beta=0.36 \mathrm{p}=0.00 \mathrm{p}<.01)$. Each of the four dimensions of psychological capital had also a positive and significant impact on affective commitment to change. Resilience dimension had the greatest impact $(\beta=0.368 \mathrm{p}=0.00 \mathrm{p}<.01)$, while self-efficacy had the least impact on affective commitment to change $(\beta=0.305 p=0.00 p<.01)$.

There was a positive and significant correlation between psychological empowerment and affective commitment to change, $\mathrm{r}=0.332, \mathrm{p}<0.01$ (one tailed), psychological empowerment had a significant influence on the affective commitment to change $(\beta=0.332 \mathrm{p}=0.000, \mathrm{p}<.01)$. Each of the dimensions of psychological empowerment had a positive and significant impact on affective commitment to change. Meaning had greatest effect $(\beta=0.348 \mathrm{p}=0.00 \mathrm{p}<.01)$, while self-determination has the least impact on affective commitment to change $(\beta=0.220 \mathrm{p}=0.00 \mathrm{p}<.01)$. 
The result also showed that psychological capital and psychological empowerment both had significant impact on the affective commitment to change $(\mathrm{R} 2=0.141, \mathrm{~F}=19.631, \mathrm{p}=0.00)$. The amount of change in affective commitment to change variance due to the influence of psychological capital is 0.031 , with the coefficient beta of psychological capital 0.252 and the significance $0.004(\Delta R 2=0.031, \beta=0.252, p=0.004$, $\mathrm{p}$ <.01). Meanwhile, the amount of change due to the influence of psychological empowerment is 0.011 with the psychological empowerment beta coefficient 0.152 and the significance $0.079(\Delta \mathrm{R} 2=0.011, \beta=0.152, \mathrm{p}$ $=0.079, \mathrm{p}>.01)$. Based on this calculations, it can be said that psychological capital had a greater value of influence than the psychological empowerment on affective commitment to change.

\section{Discussion}

The result showed a positive and significant impact of psychological capital on affective commitment to change. This result supported the previous study by Naotunna (2015), who found that psychological capital had a positive correlation with affective commitment to change. This finding was also in line with Avey, Wernsing and Luthans (2008) that showed psychological capital positively correlated with positive emotions and behaviors in the organization, which are considered relevant and necessary for individuals in the change process. Findings also showed that psychological empowerment had a positive impact on affective commitment to change. These findings supported Mangundjaya (2014) which suggested that psychological empowerment plays a vital role in developing employee's commitment to change. Results also showed that psychological capital had a more significant influence on affective commitment to change compared with psychological empowerment. This finding was not in line with the research by Lizar, Mangundjaya, and Rachmawan (2014) where psychological empowerment had more influence than psychological capital to individual readiness for change. The impact of individual readiness for change cannot be generalized in the level of commitment to change. Commitment to change is the most important in managing organizational change successsfully (Mangundjaya, 2013). It is more than just ready to face changes, but consistently being bound by it. In the globalization era, it is needed more than just focus on the ability of work, but also the positive personal characteristics of individuals who emphasize self-development and definite attribution as there is described well in psychological capital (Luthans, Youssef, and Avolio, 2007). From this findings, future study should be conducted.

The results also showed differences between banking and non-banking financial institutions. In banking institution, psychological empowerment had the more significant influence; meanwhile, in a non-banking institution, psychological capital had the greater impact on employee's affective commitment to change. These findings were interesting and might be due to the types of jobs and organizational culture of each organization.

There were some limitations in this research. First, it cannot be generalized to all company sectors, as this research only applies to financial institutions. Second, data collection based on self-report, which might have common method biases (Podsakoff, MacKenzie, Lee, \& Poodsakoff, 2003), as a result, further studies should be conducted using different types of data collection tools. New research is also expected to explore each dimension of psychological capital and psychological empowerment which in this study only discussed a little. Results also showed that both the influence of each of psychological capital and psychological empowerment on affective commitment to change is still smaller than the percentage variance of other factors, indicating that various other factors that might contribute on the affective commitment to change. Thus, it is necessary to continue the research, explore more about the impact of other factors on affective commitment to change.

\section{Conclusion}

From this study, it can be concluded that there is a positive and significant impact of each psychological capital and psychological empowerment on affective commitment to change. The higher the psychological 
capital, the higher will be employee's affective commitment to change. The same can be summed up in the psychological empowerment, the higher it is, the higher the affective commitment to change the person has. When compared both, psychological capital showed a greater impact on affective commitment to change than psychological empowerment.

\section{References}

Avey, J. B., Wernsing, T. S., \& Luthans, F. (2008). Can positive employees help positive organizational change? Impact of psychological capital and emotions on relevant attitudes and behaviors. The journal of applied behavioral science, 44(1), 48-70.

Herscovitch, L., \& Meyer, J. P. (2002). Commitment to organizational change: Extension of a three-component model. Journal of applied psychology, 87(3), 474.

Fulcher, J. D. (2013). An Analysis of the Common Reasons for Organizational Change Failures; an Exploration of the Contributing Roles of the Individual, the Leader, and the Environment (Doctoral dissertation, University of Maryland University College).

Lizar, A. A., Mangundjaya, W. L., \& Rachmawan, A. (2015). The role of psychological capital and psychological empowerment on individual readiness for change. The Journal of Developing Areas, 49(5), 343-352.

Luthans, F. (2002). The need for and meaning of positive organizational behavior. Journal of organizational behavior, 23(6), 695-706.

Luthans, F., Youssef, C. M., \& Avolio, B. J. (2007). Psychological capital: Developing the human competitive edge (p. 3). Oxford: Oxford University Press.

Mangundjaya, W. L. (2013). The Predictor Of Affective Commitment To Change: Attitude Vs Individual Readiness For Change. Romanian Economic and Business Review, 198.

Mangundjaya, W. (2014). Psychological empowerment and organizational task environment in commitment to change. International Journal of Business and Management, 2(2), 119.

Mangundjaya, W. L. H. (2016). Psychology in Organizational Change. Jakarta: Swasthi Adi Cita.

Bakari, H., \& Khoso, I. (2017). Psychological Determinants of Graduate Employability: A Comparative Study of Business and Agriculture Students Across Pakistan. Business \& Economic Review, 9(4), 111-138.

Palmer, I., Dunford, R., Akin, G., \& Buchanan, D. A. (2009). Managing organizational change: A multiple perspectives approach. New York: McGraw-Hill Irwin.

Turner Parish, J., Cadwallader, S., \& Busch, P. (2008). Want to, need to, ought to: employee commitment to organizational change. Journal of Organizational Change Management, 21(1), 32-52.

Podsakoff, P. M., MacKenzie, S. B., Lee, J. Y., \& Podsakoff, N. P. (2003). Common method biases in behavioral research: A critical review of the literature and recommended remedies. Journal of applied psychology, 88(5), 879.

Prasetyo, B. (2014). Considering Indonesia's Employment World Readiness in Facing MEA. RechtsVinding Online (Media Pembinaan Hukum Nasional).

Robbins, S. (2013). Organizational behavior. USA: McGraw-Hill

Seligman, M. E. (2011). Learned optimism: How to change your mind and your life: Vintage. New York.

Snyder, C. R. (Ed.). (2000). Handbook of hope: Theory, measures, and applications. Academic press.

Spreitzer, G. M. (1995). Psychological empowerment in the workplace: Dimensions, measurement, and validation. Academy of management Journal, 38(5), 1442-1465.

Spreitzer, G. M. (2008). Taking stock: A review of more than twenty years of research on empowerment at work. Handbook of organizational behavior, 1, 54-72.

Stajkovic, A. D., \& Luthans, F. (1998). Social cognitive theory and self-efficacy: Goin beyond traditional motivational and behavioral approaches. Organizational dynamics, 26(4), 62-74. 